ISSN 1392-3196 / e-ISSN 2335-8947

Zemdirbyste-Agriculture, vol. 107, No. 4 (2020), p. 345-352

DOI 10.13080/z-a.2020.107.044

\title{
The productivity and quality of Lactuca sativa as influenced by microbiological fertilisers and seasonal conditions
}

\author{
Milica STOJANOVIĆ ${ }^{1,2}$, Ivana PETROVIĆ ${ }^{3}$, Milena ŽUŽA ${ }^{1}$, Zorica JOVANOVIĆ ${ }^{3}$, \\ Đorđe MORAVČEVIĆ', Gorica CVIJANOVIĆ ${ }^{1}$, Slađana SAVIĆ ${ }^{1}$ \\ ${ }^{1}$ Megatrend University, Faculty of Biofarming \\ Bulevar maršala Tolbuhina 8, 11070 Belgrade, Serbia \\ E-mail: mima1384@hotmail.com \\ ${ }^{2}$ Iceberg Salat Centar D.O.O. \\ Vinogradska 40, 11271 Surčin, Belgrade, Serbia \\ ${ }^{3}$ University of Belgrade, Faculty of Agriculture \\ Nemanjina 6, 11080 Belgrade, Serbia
}

\begin{abstract}
Lettuce (Lactuca sativa L.) is an annual, leafy crop with a short growth in cool season. The aim of this study was to determine the effect of microbiological fertilisers, genotype and growing seasons on the fresh weight $(\mathrm{FW})$, concentration of nitrate and vitamin $\mathrm{C}$ in the rosette (head) of red lettuce. The greenhouse experiment included three cultivars ('Murai', 'Gaugin' and 'Carmesi') of red lettuce grown in fertile soil during successive growing seasons: autumn, winter and spring. Three types of microbiological fertilisers: (1) mixture of fungi and bacteria and their products, referred to as effective microorganisms (EM), (2) containing Trichoderma spp. and (3) mixture of EM and Trichoderma spp., were applied for red lettuce. Microbiological fertilisers were applied in the soil and via foliar spray before planting. Significantly higher FW of the rosette was in spring and winter than in autumn. The 'Murai' showed significantly the highest (264.7 g) FW of the rosette in spring. Trichoderma spp. fertiliser and the combination of effective microorganisms and Trichoderma spp. significantly increased FW of the rosette for the 'Murai' and 'Gaugin' grown in autumn. The highest nitrate concentration was observed for winter grown 'Carmesi' ( $805.2 \mathrm{mg} \mathrm{kg}^{-1}$ ) treated by effective microorganisms, and the lowest for spring grown 'Gaugin' $\left(62.2 \mathrm{mg} \mathrm{kg}^{-1}\right)$ without microbial fertilisers. Generally, the application of microbiological fertilisers contributed to a significantly higher concentration of nitrate in the rosette of red lettuce. The concentration of nitrate did not exceed maximum level for protected lettuce (EC No 563/2002). In spring, significantly the highest concentration of vitamin C (12.2 mg $\left.100 \mathrm{~g}^{-1} \mathrm{FW}\right)$ was found in the 'Carmesi' treated with Trichoderma spp. Microbiological fertilisers contributed to significantly higher concentration of vitamin $\mathrm{C}$ in the 'Gaugin' and 'Carmesi' grown in winter and spring.

This study indicated that genotype, treatment and growth season affected all the tested parameters highlighting the importance of application of Trichoderma spp. or the combination of Trichoderma spp. with effective microorganisms.
\end{abstract}

Key words: ascorbate, cultivar, effective microorganisms, growing season, red lettuce, rosette weight.

\section{Introduction}

Lettuce (Lactuca sativa L.) is an annual, coolseason, leafy vegetable crop belonging to Asteraceae family. Lettuce producers are particularly interested in its growing because of the shorter vegetation period and the possibility to cultivate it throughout the year. The biggest harvested area of lettuce and chicory in Europe is found in Spain as well as in Italy and Germany (FAO, http:// www.fao.org/faostat/en/\#data/QC). Lettuce is consumed as a fresh vegetable, mainly as a salad, as a minimally processed vegetable, and it is important in human diet due to its content of vitamins, minerals and antioxidants. The advantage of lettuce, eaten raw, is that it maintains more nutrients than thermally processed food (AćamovićĐoković et al., 2011).

Vitamin $\mathrm{C}$ has a significant role in the human organism contributing to iron absorption, cholesterol decrease, collagen production, immune system strengthening, and it acts as a powerful antioxidant, which can react with free radicals (Aćamović-Đoković et al., 2011). There are some pre-harvest factors influencing

Please use the following format when citing the article:

Stojanović M., Petrović I., Žuža M., Jovanović Z., Moravčević Đ., Cvijanović G., Savić S. 2020. The productivity and quality of Lactuca sativa as influenced by microbiological fertilisers and seasonal conditions. Zemdirbyste-Agriculture, 107 (4): $345-352$. DOI 10.13080/z-a.2020.107.044 
the content of vitamin $\mathrm{C}$ : genotype and selection of new cultivars, climatic conditions (especially temperature and light intensity) and agricultural practices (Magwaza et al., 2017).

Besides containing healthy compounds, lettuce belongs to a group of plants that have the ability to accumulate nitrates. Nitrate accumulation in plants depends on genetics, environmental factors and agricultural practices (e.g., types of nitrogen fertiliser and rates) (Cometti et al., 2011). Major sources of nitrate for humans include vegetables, fruits, meat products and drinking water (Brkić et al., 2017). In humans, nitrate can be converted into nitrite that can react with haemoglobin to form methaemoglobin (blue baby syndrome), or nitrite may react with amines or amides to form $N$-nitroso compounds, which are carcinogenic (Pérez-Urrestarazu et al., 2019). In order to limit the excessive use of nitrate in vegetables that can harm human health and facilitate the trade of vegetables among different countries, the European Commission (2002) set maximum levels of nitrate in lettuce grown in the open air and under cover (EC No 563/2002). Some research on spinach revealed an inverse relation between vitamin $\mathrm{C}$ and nitrate content as well as the fact that vitamin $\mathrm{C}$ can contribute to health protection through the prevention of both nitrate and nitrite conversion and formation of nitrosamine (Citak, Sonmez, 2010).

Effective microorganisms are a mixed culture preparation of beneficial microorganisms that can be found in nature containing photosynthetic bacteria, lactic acid bacteria, yeasts, actinomycetes and fungi (Wołejko et al., 2016). They can be used as inoculants to increase the diversity of microflora and influence physical and chemical characteristics of soil, decompose organic matter, stimulate plant growth and yield, decrease effects of monoculture, protect plants from diseases and help remove physiological disorders in plants (Szczech et al., 2016).

Trichoderma spp. are avirulent plant symbionts, opportunistic, cosmopolite fungi, and they represent one of the most examined genera that can be used as biofertilisers, biopesticides and soil conditioners. They can colonise plant roots and ameliorate plant nutrition, improve root growth, plant production and resistance to various stress factors (López-Bucio et al., 2015).

Nowadays, the use of effective microorganisms is gaining more attention, as these preparations are recognised as both environmentally friendly and sustainable strategies in regular agriculture practices. They can be used in conventional, organic and integrated agricultural systems to diminish the consumption of fertilisers and pesticides and to minimise their negative influence on the ecosystem. Application of the combined Trichoderma spp. and NPK fertilisers in tomato cultivation could save about $50 \%$ NPK used in production and reduce the usage of inorganic fertilisers (Molla et al., 2012). Microorganisms are responsible for mobilising nutrients (macro- and microelements) and support plant growth. For leafy vegetables, nitrates are the most important form of nitrogen (Colla et al., 2010), but they can be easily accumulated in plants as a result of an imbalance in absorption and reduction (PérezUrrestarazu et al., 2019).

Different effective microorganisms and Trichoderma spp. based fertilisers have improved the yield and enhanced the growth of the various field and fruit crops such as pea, strawberry and wheat (Mishra, Prasad, 2010; Kowalska, 2011; Sharma et al., 2012) with an emphasis on leafy and fruit vegetables such as lettuce, tomato, cucumber and spinach (Dubova et al., 2012; Molla et al., 2012; Aisha et al., 2013). Moreover, recent studies indicate a positive effect of microorganisms on quantity and quality characteristics in lettuce. The application of Trichoderma virens strain GV41 led to significantly higher fresh weight and leaf thickness in iceberg lettuce (Fiorentino et al., 2016). Additional research on the same Trichoderma spp. strain in lettuce and rocket revealed the improved nutrient uptake from the soil (especially native nitrogen), fresh weight, mineral and vitamin $\mathrm{C}$ content (Fiorentino et al., 2018).

Bacterial-algal fertiliser led to a significantly increased rosette fresh weight in leaf and romaine lettuce during spring and summer seasons, a higher total antioxidant capacity in summer romaine production compared to control plants, contributing to enhanced heat stress protection in romaine lettuce (Kopta et al., 2018). Being similar to plants, microorganisms have particular demands for environmental factors as well as certain limitations towards plants and production methods (Szczech et al., 2016).

The aim of this study was to determine the effect of different genotypes, microbiological fertilisers and growing seasons on rosette (head) fresh weight, nitrate and vitamin C content in Lactuca sativa leaves. A better understanding of interactions among plants, effective microorganisms and the environment would facilitate the practical application of biofertilisers in agriculture.

\section{Materials and methods}

Plant material. Three red lettuce (Lactuca sativa L.) cultivars 'Murai', 'Gaugin' and 'Carmesi' Rijk Zwaan were examined. These cultivars belong to three lettuce types: oak ('Murai', L. sativa var. crispa - leaf type), multi-leaf butterhead ('Gaugin', L. sativa var. capitata - head type) and lollo ('Carmesi', L. sativa var. crispaleaf type). Lettuce seedlings were grown in a glasshouse under the controlled conditions in the company Grow Rasad, Serbia. Seeds were sown in 4-cm peat cubes that were mechanically made from the substrate Potgrond $\mathrm{H}$ (Klasmann-Deilmann). Seedling production lasted for 20 days in autumn, 39 days in winter and 21 days in spring. In all seasons, seedlings were acclimatised for a few days before being transplanted in the greenhouse, at the stage of the fourth true leaf unfolded. Lettuce experiment started with transplanting seedlings in the greenhouse and finished with the harvest.

Microbiological fertilisers. Two different microbiological fertilisers were applied in the experiment. A fertiliser with effective microorganisms (EM) and their products (Candor-EM Tehnologija Ltd., Croatia) is a liquid preparation containing a mixture of different effective microorganisms isolated from natural habitats: Lactobacillus plantarum, L. casei, Streptococcus lactis, Rhodopseudomonas palustris, Rodobacter sphaeroides, Saccharomyces carevisiae, Streptomyces albus, S. griseus, Aspergillus oryzae, Bacillus subtilis, B. megaterium and Azotobacter chroccooum, $11.6 \times 10^{3}-$ $12 \times 10^{8} \mathrm{CFU}$ (colony-forming unit) $\mathrm{ml}^{-1}$. Trichoderma spp. fertiliser (Candor-EM Tehnologija Ltd.) is a powder formulation of Trichoderma viride and T. asperellum, $5 \times 10^{9} \mathrm{CFU} \mathrm{ml}{ }^{-1}$. Both fertilisers are on the list of permitted and registered fertilisers and soil conditioners for organic farming (https:/www.uzb.minpolj.gov.rs/ attachments/280_Lista_sredstava_za_ib_i_op_ze_za org_proizvodnju_na_22_06.doc).

Experimental $\bar{d}$ esign and climatic data. Red lettuce plants were grown in three successive growing 
seasons from September 2016 to June 2017: autumn - from October to December 2016, winter - from December 2016 to April 2017 and spring - from April to June 2017, at the company "Iceberg Salat Centar", Surčin, Serbia. The experiment was carried out in a greenhouse comprising an area of $256 \mathrm{~m}^{2}$ without additional heating and lighting. Before the experiment started, the soil profile had been analysed and randomised soil samples were gathered from the $0-30 \mathrm{~cm}$ depth for physical and chemical analyses. Physical analysis indicated that this soil is black marsh soil, clay loam, and chemical analysis showed sufficient levels of nitrogen $(0.22 \%)$, phosphorus $\left(58.35 \mathrm{mg} 100 \mathrm{~g}^{-1}\right)$, potassium $\left(32.45 \mathrm{mg} 100 \mathrm{~g}^{-1}\right)$ and humus $(5.02 \%)$. Since the soil was used for the intensive production of lettuce and other vegetables and showed the adequate levels of macronutrients, it was concluded that inorganic fertilisers would not be used in any experiments. Furthermore, microbiological fertilisers had not been applied in the soil or via foliar spray before the experiment. After the soil preparation, the soil was marked, microbiological fertilisers were applied, and the soil was covered with a black mulch film.

The experiment was laid out in a complete block design with four treatments: 1) control without fertilisation (C), 2) a fertiliser with effective microorganisms and their products (EM), 3) Trichoderma spp. fertiliser (T) and 4) a combination of both fertilisers $(\mathrm{EM}+\mathrm{T})$. There were three replicate plots per each treatment for every 32 plants. Dimensions of plots were 2 $\times 1 \mathrm{~m}$, the distance among plants was $25 \times 25 \mathrm{~cm}, 50 \mathrm{~cm}$ among repetitions, $100 \mathrm{~cm}$ among treatments, and the buffer zone was $100 \mathrm{~cm}$ at the very entrance and towards the exit of the greenhouse.
Before transplanting, the soil was treated with microbiological fertilisers: $150 \mathrm{ml} \mathrm{EM}, 21 \mathrm{~g}$ T and $150 \mathrm{ml}$ $+21 \mathrm{~g} \mathrm{EM}+\mathrm{T}$ were dissolved in $10 \mathrm{~L}$ of water. During the vegetation period, microbiological fertilisers were foliar applied four times. The first treatment was applied considering the plant coverage: 'Murai' 19.4\%, 'Gaugin' $8.1 \%$ and 'Carmesi' $13.2 \%$, while the other treatments were applied at proper intervals, regarding the expected duration of the vegetation period, following a simple rule that 7 days before harvesting all treatments should be finished. A foliar application included $30 \mathrm{ml} \mathrm{EM}, 12 \mathrm{~g}$ $\mathrm{T}$ and $30 \mathrm{ml}+12 \mathrm{~g} \mathrm{EM}+\mathrm{T}$, dissolved in $6 \mathrm{~L}$ of water. Microbiological fertilisers were applied in the soil and foliarly using the battery sprayer with drift guard nozzles.

During the experiment, regular cultural practices for lettuce greenhouse production were applied: irrigation, hoeing, weeding, preventive protection against diseases and pests, ventilation. Plants were irrigated by sprinklers (type NaanDan Jain 501-U), and water requirement was calculated by taking into account physical characteristics of the soil, plant needs and climatic data. All cultivars were harvested by hand, on the same day, when they reached a marketable size and were mature for consumption. During the experiment, climatic data were collected by RC-4HC Data Logger (Elitech Technology Inc., USA), which measured air temperature and air relative humidity for 24 hours (Table 1). In all seasons, plants were exposed to different day lengths - photoperiods (Weather Underground, https://www. wunderground.com/).

Data collection and analysis. After the harvest, rosette (head) fresh weight (FW) was measured using a scale and the results are presented in grams $(\mathrm{g})$, as

Table 1. The cultivation and climatic data during three growing seasons

\begin{tabular}{|c|c|c|c|}
\hline & Autumn & Winter & Spring \\
\hline \multicolumn{4}{|c|}{ Cultivation data } \\
\hline Sowing & 19 September, 2016 & 15 November, 2016 & 5 April, 2017 \\
\hline Transplanting & 11 October, 2016 & 27 December, 2016 & 27 April, 2017 \\
\hline Harvesting & 7 December, 2016 & 5 April, 2017 & 5 June, 2017 \\
\hline Experiment duration (days) & 58 & 100 & 40 \\
\hline \multicolumn{4}{|c|}{ Climatic data } \\
\hline Average day air temperature ${ }^{1}{ }^{\circ} \mathrm{C}$ & 11.9 & 10.8 & 26.3 \\
\hline Average night air temperature ${ }^{\circ}{ }^{\circ} \mathrm{C}$ & 5.7 & 1.8 & 15.3 \\
\hline Average maximum air temperature ${ }^{1}{ }^{\circ} \mathrm{C}$ & 17.3 & 24.1 & 30.4 \\
\hline Average minimum air temperature ${ }^{\circ} \mathrm{C}$ & -1.8 & -6.9 & 12.8 \\
\hline Average air humidity ${ }^{1} \%$ & 87.2 & 81.5 & 74.2 \\
\hline Photoperiod $^{1} \mathrm{~h}$ & $11-9$ & $9-13$ & $14-15$ \\
\hline
\end{tabular}

${ }^{1}$ - the period from the date of transplanting to the harvest

a mean of three replicates. Fresh leaf samples were packed in plastic bags and stored at $-20^{\circ} \mathrm{C}$ temperature for vitamin $\mathrm{C}$ analysis. Fresh leaves were dried in an oven at $70^{\circ} \mathrm{C}$ temperature for $72 \mathrm{~h}$ to a constant weight. Dried samples were used to determine the nitrate content in lettuce leaves.

To determine the nitrate content in lettuce leaves, rapid colourimetric determination of nitrate by nitration of salicylic acid reported by Cataldo et al. (1975) with nitrite removed by adding sulfamic acid (Jana, Moktan, 2013) was used. This method is based on a derivate, which is formed between nitrate and salicylic acid. High concentrations of nitrite can form a derivate with salicylic acid, and it has to be removed from the sample. First, sulfamic acid (Sigma Aldrich) is added to remove nitrite from the sample, and then salicylic acid (Sigma Aldrich) can form nitrosalicylic acid in acidic conditions. After that, acidity $(\mathrm{pH})$ is brought to about 12 in order to form a chromophore with maximum absorbance at 410 to $420 \mathrm{~nm}$. Nitrate content is expressed as $\mathrm{mg} \mathrm{kg}^{-1} \mathrm{FW}$, that is as the mean of three replicates per treatment.

The vitamin $\mathrm{C}$ content in lettuce leaves was determined according to Stevens et al. (2006). Lettuce leaves were milled using liquid nitrogen with the addition of $6 \%$ trichloroacetic acid (TCA) (Sigma Aldrich), and the supernatant was used for further analysis. For each sample, two tests were performed to measure total and reduced ascorbates. The total ascorbate was measured with the addition of dithiothreitol (DTT) (Sigma Aldrich). After the incubation at $37^{\circ} \mathrm{C}$ temperature, N-ethylmaleimide (NEM) (Sigma Aldrich) was added in a microplate and then $80 \mu \mathrm{L}$ of a colour reagent. The second test to measure reduced ascorbate was performed with the exclusion of DTT and was replaced with phosphate buffer ( $\mathrm{pH} 7.4)$. Absorbance was recorded at $550 \mathrm{~nm}$ using a Tecan microplate reader - Tecan Sunrise 
spectrophotometer (Tecan Group, Switzerland). The vitamin $\mathrm{C}$ content is expressed as total ascorbate $\mathrm{mg}$ $100 \mathrm{~g}^{-1} \mathrm{FW}$, that is as the mean of three replicates per treatment.

Statistical analysis. A three-way analysis of variance (ANOVA) was used to test the effects of genotype, treatment and growing season together with the post-hoc Tukey's test. We used a completely randomised design, and all terms in this model were statistically significant. For that reason, within the posthoc analysis, means of one factor by fixing the levels of the other two factors were compared. All results were calculated at a significance level of $\alpha$ of 0.05 , and values followed by the same letter were not significantly different at the $0.05 \%$ level of probability according to the Tukey's test. The correlation coefficients were used to test relationships between rosette (head) fresh weight, nitrate and vitamin $\mathrm{C}$ content. Statistical analysis was performed by using SPSS Statistics for Windows, version 22.0 (SPSS Inc., USA) and Microsoft Office Excel, version 2007 (Microsoft Corp., USA).

\section{Results and discussion}

Lettuce rosette (head) fresh weight (FW) ranged between 58.3-118.3 $\mathrm{g}$ in autumn, 139.0-232.0 $\mathrm{g}$ in winter and 166.3-264.7 $\mathrm{g}$ in spring (Table 2). In control conditions, the 'Murai' showed the highest rosette FW $(264.7 \mathrm{~g})$ in spring, whereas the lowest FW (58.3 g) was observed in the 'Carmesi' in autumn.
The cultivar (genotype) may have a great impact on rosette FW in lettuce (Govedarica-Lučić et al., 2014). In the present study, the 'Murai' and 'Gaugin' showed significantly higher rosette FW with the application of combined fertilisers and Trichoderma spp. in autumn compared to control plants. Probably, combining of these two fertilisers $(\mathrm{EM}+\mathrm{T})$ gave better results, because microorganisms possibly had a synergistic effect on FW. On the contrary, in winter and spring, the combined fertilisers led to significantly decreased rosette FW in the 'Gaugin' and 'Murai'. Various experiments with Trichoderma spp. fertiliser and effective microorganisms showed improved FW and yield. The application of Trichoderma lignorum (dose $20 \mathrm{~g} \mathrm{~m}^{-2}$ ) produced higher yield and dry weight in leaf lettuce type (Dubova et al., 2012). Experiments with the fertiliser Bioaktiv (containing Bacillus subtilis, Azobacter sp., Penicillium oxalicum and Fusarium sp.) showed higher lettuce FW (yield) and earlier head formation compared to nontreated plants (Tošić et al., 2016).

Microorganisms can produce hormones, vitamins, enzymes and other plant growth promoting compounds that can enhance nutrient availability and uptake and influence both plant growth and yield (López-Bucio et al., 2015). The efficiency of effective microorganisms and Trichoderma spp. on plant growth and yield depends on plant species, the ability of Trichoderma spp. to colonise roots, soil type and quantity of humus as well as on continuous application. Exudates of pea and maize strongly initiate mycelia growth of

Table 2. Rosette (head) fresh weight of different Lactuca sativa genotypes as affected by microbiological fertilisers in three growing seasons

\begin{tabular}{|c|c|c|c|c|c|}
\hline Season & Cultivar & Control & $\begin{array}{c}\text { Effective } \\
\text { microorganisms } \\
\text { (EM) }\end{array}$ & $\begin{array}{l}\text { Trichoderma spp. } \\
\text { (T) }\end{array}$ & $\mathrm{EM}+\mathrm{T}$ \\
\hline \multirow{3}{*}{ Autumn } & Murai & $91.0 \pm 2.3 \mathrm{bAx}$ & $90.7 \pm 8.4 \mathrm{aAx}$ & $108.3 \pm 2.0 \mathrm{cA}, \mathrm{Bx}$ & $118.3 \pm 0.7 \mathrm{bBx}$ \\
\hline & Gaugin & $64.0 \pm 7.6 \mathrm{a}, \mathrm{bAx}$ & $78.7 \pm 6.4 \mathrm{aA}, \mathrm{Bx}$ & $95.3 \pm 0.7 \mathrm{bBx}$ & $94.3 \pm 3.8 \mathrm{aBx}$ \\
\hline & Carmesi & $58.3 \pm 8.3 \mathrm{aAx}$ & $72.3 \pm 8.7 \mathrm{aAx}$ & $71.7 \pm 4.6 \mathrm{aAx}$ & $89.0 \pm 5.5 \mathrm{aAx}$ \\
\hline \multirow{3}{*}{ Winter } & Murai & $213.7 \pm 25.2 \mathrm{aAy}$ & $220.7 \pm 18.2 \mathrm{bAy}$ & $186.0 \pm 9.5$ aAy & $182.3 \pm 14.8$ aAy \\
\hline & Gaugin & $232.0 \pm 8.1 \mathrm{aBy}$ & $203.7 \pm 14.2 \mathrm{a}, \mathrm{bA}, \mathrm{By}$ & $232.0 \pm 13.9 \mathrm{aBy}$ & $170.7 \pm 2.7 \mathrm{aAy}$ \\
\hline & Carmesi & $161.3 \pm 27.7 \mathrm{aAy}$ & $139.0 \pm 11.5 \mathrm{aAy}$ & $206.3 \pm 13.0 \mathrm{aAy}$ & $160.0 \pm 11.6 \mathrm{aAx}, \mathrm{y}$ \\
\hline \multirow{3}{*}{ Spring } & Murai & $264.7 \pm 4.6 \mathrm{bBy}$ & $229.0 \pm 5.9$ aA,By & $215.7 \pm 24.9$ aA,By & $178.3 \pm 13.2 \mathrm{aAy}$ \\
\hline & Gaugin & $198.7 \pm 12.2 \mathrm{aAy}$ & $198.3 \pm 18.8$ aАy & $201.7 \pm 7.8$ aАy & $166.3 \pm 15.4$ aAy \\
\hline & Carmesi & $206.3 \pm 10.5 \mathrm{aAy}$ & $179.3 \pm 3.5 \mathrm{aAz}$ & $201.3 \pm 12.4 \mathrm{aAy}$ & $174.7 \pm 27.1 \mathrm{aAy}$ \\
\hline
\end{tabular}

Note. Data are means $(\mathrm{n}=3) \pm \mathrm{SE}$; differences between: a, b, c - cultivars (see methods), A, B, C, D - treatments, $\mathrm{x}, \mathrm{y}, \mathrm{z}-$ seasons.

T. harzianum, T. viride and T. longibrachiatum, whereas lettuce exudates contributed slightly to it or mycelia growth was inhibited by exudates of cabbage and onion (Celar, 2002). The results of the 4-year study in the temperate climate of Switzerland did not show a positive influence of effective microorganisms neither on the potato, winter barley and lucerne yields nor on the microbial activity and biomass in the soil (Mayer et al., 2010). The application of all microbiological fertilisers in the 'Carmesi' did not increase rosette FW in all seasons, which may be explained by genotype special reaction (exudates) and effective microorganisms and Trichoderma spp. or by the fertiliser dosage.

The application of $1 \mathrm{~kg} \mathrm{ha}^{-1}$ of Trichoderma spp. fertiliser (T. viride, T. harzianum and T. polysporum) did not improve onion yield, which can be regarded as the insufficient quantity for Trichoderma spp. to react (Poldma et al., 2001). On the contrary, a significant increase of cucumber yield was obtained using a dosage of $40 \mathrm{~kg} \mathrm{ha}^{-1}$ (Altintas, Bal, 2005). In the current experiment, $2.5 \mathrm{~kg} \mathrm{ha}^{-1}$ Trichoderma spp. was used, which can be a low dosage for Trichoderma spp., as suggested by the mentioned authors. There is a possibility that with an increased quantity of Trichoderma spp., especially in winter and spring season, with continuous use, a more effective response in plants can get and this can lead to an increase in the population of Trichoderma spp. in the soil.

Soil microorganisms are mostly mesophilic and tolerant of low temperatures (Kredics et al., 2003). In winter experiment, during the first few weeks, the temperatures were below $0^{\circ} \mathrm{C}$, and they probably had a negative effect on soil microorganisms. In spring season, temperatures during a day were above $30^{\circ} \mathrm{C}$, and they could negatively affect soil microorganisms. This could probably be a reason for lower FW with the application of microorganisms during winter and spring. Currently, there is little information available about the relation among effective microorganism continuous applications in plant production for different growing seasons, which can be used as an explanation.

Significantly higher rosette FW was measured in spring and winter compared to in autumn in all cultivars. The season affected rosette FW in all cultivars and treatments. Rosette FW increased from autumn 
(short day, 11-9 h) to winter (growing day, 9-13 h) and spring (long day, 14-15 h), which can be better explained by day length (photoperiod) than by the temperature.

The optimal temperatures for lettuce vegetative growth are $21-23 / 15-18^{\circ} \mathrm{C}$ day/night. Average day/ night temperatures in autumn $\left(11.9 / 5.7^{\circ} \mathrm{C}\right)$ and winter $\left(10.8 / 1.8^{\circ} \mathrm{C}\right)$ were suboptimal (Table 1$)$. In the winter season, two days after transplanting, plants were exposed to cold stress with the minimum temperature of $-16.6^{\circ} \mathrm{C}$ (data not shown). Cold stress lasted for 56 days, in which plants were exposed to temperatures below $0^{\circ} \mathrm{C}$. In the spring season, average day/night temperatures were almost optimal $\left(26.3 / 15.3^{\circ} \mathrm{C}\right)$, emphasising that during the day plants were exposed to temperatures above $30^{\circ} \mathrm{C}$ (Table 1). Experiments with cos lettuce in glasshouse cultivation in the Mediterranean climate region indicate that lettuce plants in autumn have smaller yield and biomass compared to winter and spring seasons due to short day and sunshine duration (Konstantopoulou et al., 2012).
Nitrate content in lettuce leaves ranged between $315.9-628.5 \mathrm{mg} \mathrm{kg}^{-1} \mathrm{FW}$ in autumn, 374.7$805.2 \mathrm{mg} \mathrm{kg}^{-1} \mathrm{FW}$ in winter and $62.2-498.1 \mathrm{mg} \mathrm{kg}^{-1}$ FW in spring (Table 3). In winter, the 'Carmesi' showed the highest level of nitrate content in all treatments (777.7 $\mathrm{mg} \mathrm{kg}^{-1} \mathrm{FW}$ in control and $805.2 \mathrm{mg} \mathrm{kg}^{-1} \mathrm{FW}$ with EM). The lowest nitrate content in all treatments was found in the 'Gaugin' in spring: $62.2 \mathrm{mg} \mathrm{kg}^{-1} \mathrm{FW}$ in control and $130.0 \mathrm{mg} \mathrm{kg}^{-1} \mathrm{FW}$ with $\mathrm{EM}+\mathrm{T}$.

The nitrate level in lettuce depends on the type and cultivar (Govedarica-Lučić, Perković, 2013). The results of current experiment showed that the 'Carmesi' accumulated the highest nitrate content in all treatments during winter and spring. This could be explained by the genetic effect for nitrate accumulation of this cultivar. Since nitrates have shown a negative effect on human health, it is necessary to consider this fact as well as the dosage of fertilisers for this cultivar. The 'Carmesi' also showed the lowest rosette FW in all treatments, and it is possible that nitrates were accumulated in leaves, did

Table 3. The nitrate content in Lactuca sativa leaves as affected by microbiological fertilisers in three growing seasons

\begin{tabular}{|c|c|c|c|c|c|}
\hline Season & Cultivar & Control & $\begin{array}{c}\text { Effective } \\
\text { microorganisms } \\
\text { (EM) }\end{array}$ & $\begin{array}{l}\text { Trichoderma spp. } \\
\text { (T) }\end{array}$ & $\mathrm{EM}+\mathrm{T}$ \\
\hline \multirow{3}{*}{ Autumn } & Murai & $628.5 \pm 15.4 \mathrm{bAz}$ & $607.1 \pm 60.1$ bAy & $627.1 \pm 31.7 \mathrm{cAz}$ & $472.4 \pm 60.6 \mathrm{a}, \mathrm{bAx}$ \\
\hline & Gaugin & $342.4 \pm 22.0 \mathrm{aAy}$ & $413.0 \pm 27.0 \mathrm{aA}, \mathrm{By}$ & $480.2 \pm 21.3 \mathrm{bB}, \mathrm{Cz}$ & $550.8 \pm 35.0 \mathrm{bCy}$ \\
\hline & Carmesi & $315.9 \pm 39.1 \mathrm{aAx}$ & $331.3 \pm 16.8 \mathrm{aAx}$ & $329.4 \pm 28.7 \mathrm{aAx}$ & $333.9 \pm 37.8 \mathrm{aAx}$ \\
\hline \multirow{3}{*}{ Winter } & Murai & $374.7 \pm 18.5$ aAy & $455.5 \pm 35.0 \mathrm{aA}, \mathrm{By}$ & $514.4 \pm 1.2 \mathrm{bBy}$ & $505.1 \pm 29.2 \mathrm{a}, \mathrm{bBx}$ \\
\hline & Gaugin & $495.8 \pm 44.8 \mathrm{aAz}$ & $491.3 \pm 55.0$ aAy & $379.8 \pm 5.9$ aAy & $401.5 \pm 57.3 \mathrm{aAy}$ \\
\hline & Carmesi & $777.7 \pm 68.9 \mathrm{bAy}$ & $805.2 \pm 63.3 \mathrm{bAy}$ & $645.3 \pm 16.9 \mathrm{cAz}$ & $700.5 \pm 63.8$ bAy \\
\hline \multirow{3}{*}{ Spring } & Murai & $89.1 \pm 2.8 \mathrm{aAx}$ & $198.7 \pm 16.7 \mathrm{aBx}$ & $231.0 \pm 8.1 \mathrm{bBx}$ & $382.7 \pm 33.4 \mathrm{bCx}$ \\
\hline & Gaugin & $62.2 \pm 2.3 \mathrm{aAx}$ & $134.8 \pm 7.0 \mathrm{aBx}$ & $165.8 \pm 19.1 \mathrm{aBx}$ & $130.0 \pm 1.5 \mathrm{aBx}$ \\
\hline & Carmesi & $367.2 \pm 15.1 \mathrm{bAx}$ & $498.1 \pm 20.5 \mathrm{bBx}$ & $440.4 \pm 10.1 \mathrm{cBy}$ & $448.6 \pm 8.3 \mathrm{bBx}$ \\
\hline
\end{tabular}

Explanation under Table 2

not convert to ammonium ion and were used for the synthesis of organic compounds. A high level of nitrogen affects protein synthesis and decreases the content of carbohydrates, which are essential for vitamin C (Szczech et al., 2016). The 'Gaugin' as butterhead lettuce did not accumulate the highest nitrate content. The results of current experiment are opposite to those, which indicate that head lettuce accumulates more nitrates than leaf lettuce (Siomos et al., 2002).

Combined fertilisers and Trichoderma spp. led to a significantly higher nitrate content compared to the control in the 'Gaugin' (autumn) and 'Murai' (winter). In the spring trial, all tested fertilisers contributed to a higher nitrate content in all cultivars. This can be explained by the increased availability of nutrients in the soil and by effective microorganisms that can stimulate nutrient uptake. Experiment with lettuce and rocket did indicate that Trichoderma spp. fertiliser affected plants, in a way to uptake nitrogen from the soil, especially the native nitrogen (Fiorentino et al., 2018). The application of two Trichoderma harzianum strains (T969 and T447) showed a higher concentration of phosphorus (P) and potassium $\left(\mathrm{K}^{+}\right)$in the shoots and roots of tomato seedlings (Azarmi et al., 2011). A synergistic effect of two bacterial strains stimulated nitrogen uptake by plants treated with microbiological fertilisers as transplants (Szczech et al., 2016).

The season affected the nitrate content in all cultivars and treatments except in the 'Murai' with EM $+\mathrm{T}$. Generally, the highest nitrate content was measured in autumn and winter and the lowest level - in spring. Results of our experiment are in agreement with the fact that a higher nitrate content is expected during a short day and low light intensity with a reduced nitrate reductase activity (Govedarica-Lučić, Perković, 2013). The nitrate content in all treatments was between $62.2-805.2 \mathrm{mg} \mathrm{kg}^{-1}$ $\mathrm{FW}$; results of our experiment are in the range or even lower than those found by Brkić et al. (2017). Regarding of all seasons, genotypes and treatments, the nitrate content stayed within the limit of European Commission (2002) (EC No 563/2002) for protected lettuce and below the maximum level, indicating that it is safe for human consumption.

Vitamin C content in lettuce leaves ranged between $5.4-10.7 \mathrm{mg} 100 \mathrm{~g}^{-1} \mathrm{FW}$ in autumn, 4.2-9.7 $\mathrm{mg} 100 \mathrm{~g}^{-1} \mathrm{FW}$ in winter and $4.0-12.2 \mathrm{mg} 100 \mathrm{~g}^{-1} \mathrm{FW}$ in spring (Table 4). In control, the highest level of vitamin C was measured in the 'Gaugin' in autumn $\left(10.7 \mathrm{mg}^{100 \mathrm{~g}^{-1}}\right.$ $\mathrm{FW}$ ) and the lowest - in the 'Carmesi' in spring (4.0 mg $\left.100 \mathrm{~g}^{-1} \mathrm{FW}\right)$.

Genotype had a great impact on the vitamin C content in five lettuce types: iceberg, lollo rosso, red oak, continental and romaine (Llorach et al., 2008). The results of our experiment were in the range between $2.8-19.5 \mathrm{mg}$ $100 \mathrm{~g}^{-1} \mathrm{FW}$ found by Llorach et al. (2008) in different lettuce types. In our study, the 'Murai' showed a higher content of vitamin $\mathrm{C}$ in all treatments compared to the results of Aćamović-Đoković et al. (2011) employing the same cultivar and season. The vitamin $\mathrm{C}$ content depends on the lettuce type and a higher content is expected in leaf rather than in head lettuce (Aćamović-Đoković et al., 2011). Most of the current results are in agreement with those, but, in some cases, butterhead lettuce had a higher content than leaf lettuce. Butterhead lettuce leaves were more opened and exposed to light without forming a compact head (Siomos et al., 2002). Compared to control, a significant increase in the vitamin $\mathrm{C}$ content was determined when using the effective microorganisms 
Table 4. The vitamin C content in Lactuca sativa leaves as affected by microbiological fertilisers in three growing seasons

\begin{tabular}{|c|c|c|c|c|c|}
\hline Season & Cultivar & Control & $\begin{array}{c}\text { Effective } \\
\text { microorganisms } \\
(\mathrm{EM})\end{array}$ & Trichoderma spp. (T) & $\mathrm{EM}+\mathrm{T}$ \\
\hline \multirow{3}{*}{ Autumn } & Murai & $7.1 \pm 0.2 \mathrm{aAx}$ & $6.0 \pm 0.6 \mathrm{aAy}$ & $5.4 \pm 0.3 \mathrm{aAx}$ & $6.4 \pm 0.6 \mathrm{aAx}$ \\
\hline & Gaugin & $10.7 \pm 0.3 \mathrm{bDy}$ & $8.9 \pm 0.2 \mathrm{bCz}$ & $6.8 \pm 0.4 \mathrm{a}, \mathrm{bBy}$ & $5.5 \pm 0.2 \mathrm{aAx}$ \\
\hline & Carmesi & $10.0 \pm 0.9 \mathrm{bBy}$ & $7.4 \pm 0.8 \mathrm{a}, \mathrm{bA}, \mathrm{Bx}$ & $7.2 \pm 0.3 \mathrm{bA}, \mathrm{By}$ & $6.7 \pm 0.7 \mathrm{aAx}, \mathrm{y}$ \\
\hline \multirow{3}{*}{ Winter } & Murai & $6.0 \pm 0.8 \mathrm{aAx}$ & $4.2 \pm 0.2 \mathrm{aAx}$ & $4.2 \pm 0.6 \mathrm{aAx}$ & $5.0 \pm 0.3 \mathrm{aAx}$ \\
\hline & Gaugin & $5.6 \pm 0.2 \mathrm{aBx}$ & $4.3 \pm 0.3 \mathrm{aAx}$ & $4.8 \pm 0.1 \mathrm{aA}, \mathrm{Bx}$ & $4.8 \pm 0.2$ aA,, $\mathrm{Bx}$ \\
\hline & Carmesi & $6.2 \pm 0.9 \mathrm{aAx}$ & $9.7 \pm 0.4 \mathrm{bBx}$ & $4.7 \pm 0.4 \mathrm{aAx}$ & $4.7 \pm 0.1 \mathrm{aAx}$ \\
\hline \multirow{3}{*}{ Spring } & Murai & $6.3 \pm 0.2 \mathrm{bBx}$ & $4.1 \pm 0.2 \mathrm{aAx}$ & $5.7 \pm 0.4 \mathrm{aBx}$ & $5.2 \pm 0.4 \mathrm{aA}, \mathrm{Bx}$ \\
\hline & Gaugin & $4.2 \pm 0.5 \mathrm{aAx}$ & $5.5 \pm 0.1 \mathrm{bAy}$ & $7.6 \pm 0.5 \mathrm{bBy}$ & $7.6 \pm 0.3 \mathrm{bBy}$ \\
\hline & Carmesi & $4.0 \pm 0.2 \mathrm{aAx}$ & $9.4 \pm 0.4 \mathrm{cCx}$ & $12.2 \pm 0.5 \mathrm{cDz}$ & $7.1 \pm 0.5 \mathrm{bBy}$ \\
\hline
\end{tabular}

Explanation under Table 2

in the 'Carmesi' (winter), the Trichoderma spp. and a combination of both fertilisers in the 'Gaugin' (spring) and all fertilisation treatments in the 'Carmesi' (spring). A significant decrease in the vitamin $\mathrm{C}$ content was determined in autumn, when were used all fertilisation treatments in the 'Gaugin', a combination of both fertilisers in the 'Carmesi' and effective microorganisms in the 'Gaugin' (winter) and 'Murai' (spring). The 'Carmesi' showed the highest vitamin $\mathrm{C}$ content (12.2 mg $100 \mathrm{~g}^{-1} \mathrm{FW}$ ) with the Trichoderma spp. in spring.

The experiment with Trichoderma virens strain GV41 led to higher vitamin C content in rocket with optimal and high nitrogen fertilisation, whereas in lettuce the highest content was determined in non-fertilised conditions, regardless of Trichoderma spp. inoculation (Fiorentino et al., 2018). Experiment with a natural algae extract showed higher vitamin $\mathrm{C}$ content in butterhead lettuce grown in the non-heated plastic tunnel (Dudaš et al., 2016). In the control treatment, the highest vitamin $\mathrm{C}$ content was measured in autumn (short day). Similar results, where the highest vitamin $\mathrm{C}$ content in lettuce head was obtained in the control treatment, were significantly different from the treatment with bacterial strains (Szczech et al., 2016). This result is in contradiction with the results of Fu et al. (2017), which imply that vitamin $\mathrm{C}$ content is increased with a high light intensity. Light intensity and quantity may have an impact on vitamin $\mathrm{C}$ content due to the photosynthetic rate, but this effect remains unknown (Kosma et al., 2013).

Generally, higher concentrations of vitamin $\mathrm{C}$ content were determined in autumn and spring compared to winter. The highest level of vitamin $\mathrm{C}$ in autumn, in control, could also indicate that plants were exposed to some environmental factors that could lead to the accumulation of vitamin $\mathrm{C}$ as an antioxidant component. During the autumn season (1-4 weeks after transplanting), air temperatures were mostly optimal, and in the second half of vegetation period, they were suboptimal leading to temperatures below $0^{\circ} \mathrm{C}$ ten days before the harvest (average minimum air temperature was $-1.8^{\circ} \mathrm{C}$ ). Low vitamin $\mathrm{C}$ content in spring was improved by microbiological fertilisers in the 'Gaugin' and 'Carmesi'. Vitamin C content remained more or less stable and independent of seasons and fertilisers (control, Trichoderma spp. and EM + T) in the 'Murai' and of EM in the 'Carmesi'.

The results of current experiment showed that Trichoderma spp. and a combination of fertilisers had a great influence on the observed parameters. The further investigation of studied cultivars (especially 'Carmesi') will focus on both quantity optimization and continuous application of microbiological fertilisers in order to improve lettuce FW and quality parameters.
Correlation coefficients between tested parameters, as a measure of the intensity of association between certain traits, represents a significant genetic, agrotechnical and economic tool in plant production, which directly indicates all interdependent parameter relations. The correlation coefficients $(r)$ are presented in Table 5. The results showed significant negative relationships between rosette (head) $\mathrm{FW}$, nitrate and vitamin $\mathrm{C}$ contents $\left(r=-0.25^{*}, r=-0.42 *\right)$.

Table 5. Correlation coefficients ( $r$ ) between Lactuca sativa rosette (head) nitrate and vitamin $\mathrm{C}$ contents and fresh weight (FW)

\begin{tabular}{lccc}
\hline \multicolumn{1}{c}{ Correlation } & $\begin{array}{c}\text { Nitrate } \\
\text { content }\end{array}$ & $\begin{array}{c}\text { Vitamin C } \\
\text { content }\end{array}$ & $\begin{array}{c}\text { Rosette } \\
\text { FW }\end{array}$ \\
\hline Nitrate content & 1 & & \\
Vitamin C content & $0.05 \mathrm{~ns}$ & 1 & \\
Rosette FW & $-0.25^{*}$ & $-0.42^{*}$ & 1 \\
\hline
\end{tabular}

* - significant at $P<0.05$ level; ** - significant at $P<0.01$ level; ns - non-significant

An increase in rosette FW, caused by different agroecological conditions and genotypes (GovedaricaLučić, Perković, 2013), significantly affects nitrate and vitamin $\mathrm{C}$ contents, negatively and positively (Reinink, 1993; Kosma et al., 2013). Some research showed no correlation between these parameters (M'hamdi et al., 2014). Results of our experiment showed that with increased rosette FW one can expect an increased photosynthetic activity and lower nitrate content in lettuce leaves as a result of their conversion in ammonium ion. High crop yields are often the main goal in intensive agriculture, and special attention must be paid to the healthy and safe production of lettuce, especially when the conditions are not optimal.

\section{Conclusions}

1. The lettuce cultivar 'Murai' showed significantly the highest rosette (head) fresh weight (FW) in spring $(264.7 \mathrm{~g} \mathrm{FW})$, and it can be recommended for growing in all seasons to obtain high rosette FW. The application of microbiological (Trichoderma spp. (T) and combined T + EM (effective microorganisms) fertilisers significantly increased rosette $\mathrm{FW}$ in autumn, while in winter and spring microbiological fertilisers had either negative or no effect on FW. Significantly higher FW was obtained in spring and winter compared to autumn.

2. The lowest nitrate level was achieved in the 'Gaugin' during the spring trial in the control treatment (62.2 $\mathrm{mg} \mathrm{kg}^{-1} \mathrm{FW}$ ). The 'Carmesi' showed a tendency 
to higher accumulation of nitrates than other cultivars during three growing seasons. Nitrate levels were below the European Commission (2002) maximum level for protected lettuce. Generally, in all growing seasons, microbiological fertilisers significantly increased the nitrate content in red lettuce leaves.

3. The 'Carmesi' showed significantly the highest content of vitamin $\mathrm{C}\left(12.2 \mathrm{mg} 100 \mathrm{~g}^{-1} \mathrm{FW}\right)$ in spring with Trichoderma spp. The application of microbiological fertilisers led to significantly higher vitamin $\mathrm{C}$ content in spring and winter, while in autumn fertilisers generally significantly lowered vitamin C content. Such response suggests the importance of the appropriate selection of fertilisers and dosages in combination with cultivars and seasons.

4. Significantly negative correlations between rosette $\mathrm{FW}$ and quality parameters could indicate that increased rosette FW could lead to a significant decrease in nitrate and vitamin $\mathrm{C}$ contents.

\section{Acknowledgements}

The authors are grateful to the company "Iceberg Salat Centar", Belgrade, Serbia, its owner Predrag Popović and the employees for funding and technical support, then to Zoran Dinić from the Institute of Soil Science, Belgrade, Serbia for collaboration and analysis of the soil, and to Dr. Dragosav Mutavdžić from the Institute for Multidisciplinary Research, Belgrade, Serbia for statistical analysis.

Received 22112019 Accepted 12062020

\section{References}

1. Aisha H. A., Hafez M. M., Asmaa R. M., Shafeek M. R. 2013. Effect of Bio and chemical fertilizers on growth, yield and chemical properties of spinach plant (Spinacia oleracea L.). Middle East Journal of Agriculture Research, 2 (1): 16-20.

2. Aćamović-Đoković G., Pavlović R., Mladenović J., Đurić M. 2011. Vitamin C content of different types of lettuce varieties. Acta Agriculturae Serbica, 16 (32): 83-89.

3. Altintas S., Bal U. 2005. Application of Trichoderma harzianum increases yield in cucumber (Cucumis sativus) grown in an unheated glasshouse. Journal of Applied Horticulture, 7: 25-28 https://doi.org/10.37855/jah.2005.v07i01.07

4. Azarmi R., Hajieghrari B., Giglou A. 2011. Effect of Trichoderma isolates on tomato seedling growth response and nutrient uptake. African Journal of Biotechnology, 10 (31): 5850-5855. https://doi.org/10.5897/AJB10.1600

5. Brkić D., Bošnir J., Bevardi M., Bošković A. G., Miloš S., Lasić D., Krivohlavek A., Racz A., Mojsović-Ćuić A., Uršulin-Trstenjak N. 2017. Nitrate in leafy green vegetables and estimated intake. African Journal of Traditional, Complementary and Alternative Medicines, 14 (3): 31-41. https://doi.org/10.21010/ajtcam.v14i3.4

6. Cataldo D. A., Haroon M., Schrader L. E., Youngs V. L. 1975. Rapid colorimetric determination of nitrate in plant tissue by nitration of salicylic acid. Communications in Soil Science and Plant Analysis, 6 (1): 71-80. https://doi.org/10.1080/00103627509366547

7. Celar F. 2002. Influence of root exudates of different plant seedlings on mycelial growth of antagonistic fungi Trichoderma spp. and Gliocladium roseum. Kmetijstvo (Agronomija), 79: 343-348.

8. Citak S., Sonmez S. 2010. Effects of conventional and organic fertilization on spinach (Spinacea oleracea L.) growth, yield, vitamin $\mathrm{C}$ and nitrate concentration during two successive seasons. Scientia Horticulturae, 126 (4): 415-420. https://doi.org/10.1016/j.scienta.2010.08.010

9. Colla G., Suárez C. M. C., Cardarelli M., Rouphael Y. 2010 Improving nitrogen use efficiency in melon by grafting. HortScience, 45 (4): 559-565.

https://doi.org/10.21273/HORTSCI.45.4.559
10. Cometti N. N., Martins M. Q., Bremenkamp C. A., Nunes J. A. 2011. Nitrate concentration in lettuce leaves depending on photosynthetic photon flux and nitrate concentration in the nutrient solution. Horticultura Brasileira, 29 (4): 548-553. https://doi.org/10.1590/S0102-05362011000400018

11. Dubova L., Alsina I., Steinberga V. 2012. Comparison of Trichoderma spp. use efficiency on cucumbers and lettuce. Scientific Papers. Series B. Horticulture, 56: 101-104.

12. Dudaš S., Sola I., Sladonja B., Erhatić R., Ban D., Poljuha D. 2016. The effect of biostimulant and fertilizer on "low input" lettuce production. Acta Botanica Croatica, 75 (2): $253-259$.

https://doi.org/10.1515/botcro-2016-0023

13. European Commission. 2002. Commission Regulation (EC) No 563/2002 of 2 April 2002 amending Regulation (EC) No 466/2001 setting maximum levels for certain contaminants in foodstuffs. Official Journal of the European Communities, L86: 5-6.

14. Fiorentino N., De Rosa A., Gioia L., Senatore M., Visconti D., Ottaiano L., Cenvinzo V., Cozzolino E., Rouphael Y., Woo S., Mori M. 2016. Effects of Trichoderma on growth and nitrogen uptake of lettuce (Lactuca sativa L.). Atti del XLV Convegno della Società Italiana di Agronomia, p. 134-135.

15. Fiorentino N., Ventorino V., Woo S. L., Pepe O., De Rosa A., Gioia L., Romano I., Lombardi N., Napolitano M., Colla G., Rouphael Y. 2018. Trichoderma-based biostimulants modulate rhizosphere microbial populations and improve $\mathrm{N}$ uptake efficiency, yield and nutritional quality of leafy vegetables. Frontiers in Plant Science, 9: 743. https://doi.org/10.3389/fpls.2018.00743

16. Fu Y., Li H., Yu J., Liu H., Cao Z., Manukovsky N.S., Liu H. 2017. Interaction effects of light intensity and nitrogen concentration on growth, photosynthetic characteristics and quality of lettuce (Lactuca sativa var. youmaicai). Scientia Horticulturae, 214: 51-57. https://doi.org/10.1016/j.scienta.2016.11.020

17. Govedarica-Lučić A., Perković G. 2013. Effect of variety and production methods on nitrate content in lettuce. Agroznanje, 14 (4): 541-547. https://doi.org/10.7251/AGREN1304541G

18. Govedarica-LučićA., MojevićM.,PerkovićG., Govedarica B. 2014. Yield and nutritional quality of greenhouse lettuce (Lactuca sativa L.) as affected by genotype and production methods. Genetika, 46 (3): 1027-1036. https://doi.org/10.2298/GENSR1403027G

19. Jana J. C., Moktan P. 2013. Nitrate concentration of leafy vegetables: a survey of nitrite concentrations in retail fresh leafy vegetables from daily markets of different locations. ISABB Journal of Food and Agricultural Sciences, 3 (1): 1-5.

20. Konstantopoulou E., Kapotis G., Salachas G., Petropoulos S. A., Chatzieustratiou E., Karapanos I. C., Passam H. C. 2012. Effect of nitrogen application on growth parameters, yield and leaf nitrate content of greenhouse lettuce cultivated during three seasons. Journal of Plant Nutrition, 35 (8): 1246-1254. https://doi.org/10.1080/01904167.2012.676135

21. Kopta T., Pavlikova M., Sękara A., Pokluda R., Maršálek B. 2018. Effect of bacterial-algal biostimulant on the yield and internal quality of lettuce (Lactuca sativa L.) produced for spring and summer crop. Notulae Botanicae Horti Agrobotanici Cluj-Napoca, 46 (2): 615-621. https://doi.org/10.15835/nbha46211110

22. Kosma C., Triantafyllidis V., Papasavvas A., Salahas G., Patakas A. 2013. Yield and nutritional quality of greenhouse lettuce as affected by shading and cultivation season. Emirates Journal of Food and Agriculture, 25: 974-979. https://doi.org/10.9755/ejfa.v25i12.16738

23. Kowalska J. 2011. Effects of Trichoderma asperellum [T1] on Botrytis cinerea [Pers.: Fr.], growth and yield of organic strawberry. Acta Scientiarum Polonorum Hortorum Cultus, 10 (4): 107-114.

24. Kredics L., Antal Z., Manczinger L., Szekeres A., Kevei F., Nagy E. 2003. Trichoderma strains with biocontrol potential. Food Technology and Biotechnology, 41 (1): 37-42.

25. Llorach R., Martínez-Sánchez A., Tomás-Barberán F. A., Gil M. I., Ferreres F. 2008. Characterisation of polyphenols and antioxidant properties of five lettuce varieties and escarole. Food Chemistry, 108 (3): 1028-1038. https://doi.org/10.1016/j.foodchem.2007.11.032 
26. López-Bucio J., Pelagio-Flores R., Herrera-Estrella A. 2015. Trichoderma as biostimulant: exploiting the multilevel properties of a plant beneficial fungus. Scientia Horticulturae, 196: 109-123.

https://doi.org/10.1016/j.scienta.2015.08.043

27. Magwaza L. S., Mditshwa A., Tesfay S. Z., Opara U. L. 2017. An overview of preharvest factors affecting vitamin C content of citrus fruit. Scientia Horticulturae, 216: 12-21. https://doi.org/10.1016/j.scienta.2016.12.021

28. Mayer J., Scheid S., Widmer F., Fließbach A., Oberholzer H.-R. 2010. How effective are 'Effective microorganisms ${ }^{\circledR}(\mathrm{EM})$ '? Results from a field study in temperate climate. Applied Soil Ecology, 46 (2): 230-239. https://doi.org/10.1016/j.apsoil.2010.08.007

29. M'hamdi M., Boughattas I., Rouhou H. C. Souhli E., Bettaieb T. 2014. Effect of different levels of nitrogen fertilizer on morphological and physiological parameters and nitrates accumulation of lettuce cultivars (Lactuca sativa L.). Research in Plant Biology, 4 (4): 27-38.

30. Mishra A., Prasad K. 2010. Synergism among Rhizobium, phosphate solubilizing bacteria and plant growth promoting Rhizobacteria in field pea. International Journal of Applied Agriculture Research, 5 (1): 25-30.

31. Molla A. H., Haque M. M., Haque M. A., Ilias G. N. M. 2012. Trichoderma-enriched biofertilizer enhances production and nutritional quality of tomato (Lycopersicon esculentum Mill.) and minimizes NPK fertilizer use. Agricultural Research, 1 (3): 265-272. https://doi.org/10.1007/s40003-012-0025-7

32. Pérez-Urrestarazu L., Lobillo-Eguíba J., FernándezCañero R., Fernández-Cabanás V.M. 2019. Food safety concerns in urban aquaponic production: nitrate contents in leafy vegetables. Urban Forestry and Urban Greening, 44: 126431. https://doi.org/10.1016/j.ufug.2019.126431

33. Poldma P., Merivee A., Johansson P., Ascard J., Alsanius B. 2001. Influence of biological control of fungal diseases with Trichoderma spp. on yield and quality of onion. New
Sights in Vegetable Production. Nordic Association of Agricultural Scientists, NJF-rapport No. 329, p. 48-52.

34. Reinink K. 1993. Genetics of nitrate accumulation in lettuce. Wageningen, The Netherlands, $95 \mathrm{p}$.

35. Sharma P., Patel A. N., Saini M. K., Deep S. 2012. Field demonstration of Trichoderma harzianum as a plant growth promoter in wheat (Triticum aestivum L). Journal of Agricultural Science, 4: 65. https://doi.org/10.5539/jas.v4n8p65

36. Siomos A. S., Papadopoulou P. P., Dogras C. C., Vasiliadis E., Dosas A., Georgiou N. 2002. Lettuce composition as affected by genotype and leaf position. Acta Horticulturae, 579: 635-639.

https://doi.org/10.17660/ActaHortic.2002.579.112

37. Stevens R., Buret M., Garchery C., Carretero Y., Causse M. 2006. Technique for rapid, small-scale analysis of vitamin $\mathrm{C}$ levels in fruit and application to a tomato mutant collection. Journal of Agricultural and Food Chemistry, 54 (17): 6159-6165. https://doi.org/10.1021/jf061241e

38. Szczech M., Szafirowska A., Kowalczyk W., SzwejdaGrzybowska J., Włodarek A., Maciorowski R. 2016. The effect of plant growth promoting bacteria on transplants growth and lettuce yield in organic production. Journal of Horticultural Research, 24 (2): 101-107 https://doi.org/10.1515/johr-2016-0026

39. Tošić I., Golić Z., Radosavac A. 2016. Effects of the application of biofertilizers on the microflora and yield of lettuce (Lactuca sativa L.). Acta Agriculturae Serbica, 21 (42): 91-98. https://doi.org/10.5937/AASer1642091T

40. Wołejko E., Łozowicka B., Kaczyński P., Jankowska M., Piekut J. 2016. The influence of effective microorganisms (EM) and yeast on the degradation of strobilurins and carboxamides in leafy vegetables monitored by LC-MS/MS and health risk assessment. Environmental Monitoring and Assessment, 188 (1): 64.

https://doi.org/10.1007/s10661-015-5022-4

ISSN 1392-3196 / e-ISSN 2335-8947

Zemdirbyste-Agriculture, vol. 107, No. 4 (2020), p. 345-352

DOI 10.13080/z-a.2020.107.044

\title{
Mikrobiologinių trąšų ir auginimo sezono sąlygų įtaka Lactuca sativa produktyvumui ir kokybei
}

\author{
M. Stojanović1,2, I. Petrović ${ }^{3}$, M. Žuža ${ }^{1}$, Z. Jovanović ${ }^{3}$, Đ. Moravčević ${ }^{3}$, G. Cvijanović1 ${ }^{1}$ S. Savić ${ }^{1}$ \\ ${ }^{1}$ Megatrend universiteto Bioūkininkavimo fakultetas, Serbija \\ ${ }^{2}$ Iceberg salotų centras, Serbija \\ ${ }^{3}$ Belgrado universiteto Žemès ūkio fakultetas, Serbija
}

\section{Santrauka}

Sejjamoji salota (Lactuca sativa L.) yra vienametè, vėsiu metų laiku auginama lapinè daržovè. Tyrimo tikslas nustatyti mikrobiologinių trąšų, genotipo ir augimo sezono įtaką sẻjamosios salotos gūžių žaliai masei (ŽM) ir nitratų bei vitamino C koncentracijai. Rudenị, žiemą ir pavasari šiltnamyje derlingame dirvožemyje augintos trijų veislių ('Murai', 'Gaugin' ir 'Carmesi') raudonlapès salotos. Salotos tręštos trijų rūšių mikrobiologinemis trąšomis: (1) veiksmingaisiais mikroorganizmais (EM) - grybų ir bakterijų mišiniu su jų išskyromis; (2) Trichoderma spp. ir (3) EM ir Trichoderma spp. deriniu. Mikrobiologinemis trąšomis tręšta dviem būdais: prieš auginimą įterpiant ị dirvožemị ir purškiant lapus. Pavasarị ir žiemą skrotelių žalia masė buvo žymiai didesnè nei rudenị. Pavasarị augintos 'Murai' salotos pasižymėjo reikšmingai didžiausia gūžių žalia mase (264,7 g). Rudenị išaugintų veislių 'Murai' ir 'Gaugin' salotų gūžių žalią masę žymiai padidino Trichoderma spp. trąšos ir veiksmingujų mikroorganizmų bei Trichoderma spp. derinys. Didžiausia nitratų koncentracija $\left(805,2 \mathrm{mg} \mathrm{kg}^{-1}\right)$ nustatyta žiemą užaugintose veislès 'Carmesi' salotose, apdorotose veiksmingaisiais mikroorganizmais, mažiausia $\left(62,2 \mathrm{mg} \mathrm{kg}^{-1}\right)$ - veislès 'Gaugin' salotose, pavasarį užaugintose be mikrobiologinių trąšų. Tręšiant mikrobiologinèmis trąšomis raudonlapių salotų gūžèse reikšmingai padidèjo nitratų koncentracija, tačiau ji neviršijo didžiausių salotoms leidžiamų koncentracijų

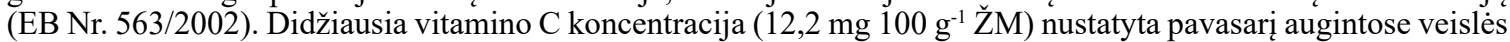
'Carmesi' salotose, tręštose Trichoderma spp. Trąšos reikšmingai padidino vitamino C koncentraciją žiemą ir pavasari augintose veislių 'Gaugin' ir 'Carmesi' salotose.

Tyrimo duomenys parodè, kad genotipas, auginimo sezonas ir tręšimas Trichoderma spp. arba Trichoderma spp. bei veiksmingụjų mikroorganizmų mišiniu buvo reikšmingi visiems tirtiems raudonlapių salotų gūžių rodikliams.

Reikšminiai žodžiai: askorbatas, gūžès svoris, raudonlapės salotos, veiksmingi mikroorganizmai, vegetacijos sezonas, veislè. 